\title{
Effects of Foreign Aid Inflow on Economic Growth of Uganda: Autoregressive Distributed Lag Modelling (ARDL)
}

\author{
Ssemanda Patrick Edward, Henry Tumwebaze Karamuriro \\ Department of Economics and Statistics, Kyambogo University, Kampala, Uganda
}

Email address:

ssemandapatrick@yahoo.com (S. P. Edward), htumwebaze@yahoo.com (H. T. Karamuriro)

\section{To cite this article:}

Ssemanda Patrick Edward, Henry Tumwebaze Karamuriro. Effects of Foreign Aid Inflow on Economic Growth of Uganda: Autoregressive Distributed Lag Modelling (ARDL). International Journal of Sustainability Management and Information Technologies.

Vol. 6, No. 2, 2020, pp. 36-49. doi: 10.11648/j.ijsmit.20200602.11

Received: February 14, 2020; Accepted: February 27, 2020; Published: August 27, 2020

\begin{abstract}
Uganda has always relied on foreign assistance to enhance its economic development and has been a recipient of foreign assistance from individual countries and from multilateral organizations. The study aims at establishing the effects of foreign aid on the economic growth of Uganda. It used annual time series data for the period 1970-2017. The hypothesis that foreign aid can promote growth was explored. This hypothesis was tested using time series data for foreign aid. An empirical model is estimated using the Autoregressive Distributed Lag (ARDL) approach to cointegration proposed by Pesaran and Shin [59]. Results show that foreign aid inflow significantly reduced economic growth in Uganda in the short run and long run. The domestic investment was significant and had a positive sign in the short run while exports increased output in the short and long run. Dummy variable for insecurity increase output in the short run and increased it in the long run. The study identified previous periods of democracy index and effective labor to have negatively affected output in the short run. In the long run, effective Labour force, exports, Dummy variable for insecurity and democratic index was found to increase output in the long run. This study contributes to the literature on foreign aid and economic growth by providing the theoretical and empirical evidence for Uganda.
\end{abstract}

Keywords: Foreign Aid, Economic Growth, Autoregressive Distributed Lag Modelling

\section{Introduction}

The role of foreign aid to economic growth continues to attract considerable attention. Aid inflows can stimulate economic growth by supplementing domestic savings thereby increasing the amount of investment and capital stock. Strong economic growth patterns are in turn associated with gains in poverty reduction and improved standards of living. The effectiveness of aid in growth and poverty reduction enhancement, presupposes that viable projects have to be identified and managed in addition to meeting the conditions for budgetary support. Increasing the effectiveness of aid requires that developing countries are helped to improve the welfare of their poorest populations. For this reason, foreign aid must be genuinely focused on development priorities set by developing countries. To enable this to happen, donors and developing countries should establish genuine partnerships, in which they are jointly and mutually responsible for development results. This calls for developing countries to fundamentally shift in the way they do business and focus on viable projects to benefit from foreign aid inflow.

Uganda's economic history has gone through four distinct episodes since independence. Between 1960 and 1970, Uganda had one of the most vibrant economies in sub-Saharan Africa. For the first five years after independence in 1962, the economy grew averagely at a rate of 6.7 per cent per year. The population growth was 2.5 per cent per year, and the people's lives were improving. By 1970 the economic growth rate was 5.6 per cent but because of civil war and political instability the once promising economy was almost destroyed and economic growth declined each year from 1972. The economy experienced domestic and external shocks, which were worsened by the absence of sound macroeconomic policies to address them. Productive sectors were ignored in pursuit of informal trade, as most skilled personnel fled the country to escape the economic mismanagement and civil unrest, in which they were often caught as soft targets. For most of the 1970s and 1980s the country suffered severe macroeconomic 
imbalances, including high rates of inflation and balance of payments deficits. By 1980, the need to rehabilitate the economy was obvious.

Structural adjustment measures, focusing on demand management, were introduced in 1981 to encourage economic growth. Because of the civil war, these structural adjustment measures could not bear fruits and the economy was plugged into further macroeconomic problems. In 1986 when a new regime of President Yoweri Kaguta Museven came into power, Uganda embarked on an Economic Recovery Programme with support from the IMF, the World Bank and other multilateral and bilateral donors. The principal objectives were to rehabilitate the economy and enhance economic growth, reduce inflation and minimize the potential for a balance of payments crisis. Because of the reforms, Uganda's budget, attracted external and domestic resources. Since 1970 to date Uganda has experienced fiscal deficits mainly because of increased public expenditure with low or decreasing revenue. In most cases, the large fiscal deficits have been funded through budget support in the form of external loans and grants. This has continued to present significant challenges to monetary and exchange rate management, resulting not only in upward pressures but also in the volatility of the exchange and interest rates. Monetary authorities use a monetary targeting framework, sterilizing shilling which is necessary to prevent the injections of liquidity translating into inflationary increases. Open market type operations and foreign exchange sales have been employed to manage liquidity and contain underlying inflation. Consequently, because money demand has not risen as fast as money supply (being injected through government expenditures) interest rates have been higher and more volatile than they might otherwise have been.

At independence, ratio of foreign aid flows to GDP accounted for $4.88 \%$ and by 2017 , it had reached $10.2 \%$. Uganda is an agricultural country and has large amounts of fertile agricultural land in addition to many other natural resources. Despite all the natural resource endowments and the large amounts of the aid inflow, Uganda has failed to prosper. Uganda witnessed unprecedented foreign aid inflow increases for half a century and it was particularly intensified during the economic recovery programme between 1986 and 1994. The increased aid inflows led to high expectations that it would assist the country realize faster economic growth and sustainable economic structural transformation that would sustain economic growth, but little development has taken place. To date, the expectations of high sustainable economic growth do not seem to be forthcoming. The average growth rate of real GDP varies only 5-6 per cent for the period of the study, a rate which Uganda obtained in the 1960 s, when aid inflow was low.

The structural change of the economy is characterized by a rising share of the services sector, the bulk of which consists of informal activities that sprung up to cope with increasing unemployment, instead of the expected sustainable structural transformation, that can be supported by imports of capital goods, in order to build a manufacturing sector with higher productivity that would raise Uganda's economic growth rate and productive employment. The interest rates have remained high for long periods which have crowded out private investment. This has constrained long-term borrowing and yet the high interest rate is still necessary to control the money supply expansion arising from increased aid inflow. The challenge for the government has been to finance the infrastructure priorities with the highest and most immediate productivity bonus, to minimize the gestation lags between the initial inflow and the stream of benefits to firms. This has created aid dependence and the government cannot decide to raise taxes or lower spending as it would not be welfare enhancing in the short-medium term and very many people would be hurt.

The trade balance has persistently remained negative; with a widening foreign exchange gap as export receipts could not fund the import requirements. The country's rapid import growth was not followed by a programme to expand exports earning capacity. The fiscal gap is still financed by aid inflow whose disbursements, under the Budget Support (BS), is subject to volatility, as donors make irregular suspension of aid inflow because of corruption, cost share, differing ideology and other aid conditionality among others. Foreign aid inflow is expected to supplement domestic savings and increase investment to cause sustainable economic growth. If the aid increases consumption and permit a relaxation in saving effort, then sustainable economic growth cannot be achieved. In addition Uganda lacks entrepreneurial skills to invest and the injection of foreign resources through technical aid is therefore unlikely to increase investment and growth as anticipated. A critical emerging concern is whether the effects of the increased foreign aid inflow have narrowed the resource gaps sufficiently to ensure investment and then sustainable economic growth or whether instead negative effects on growth have set in. Therefore this study develops an empirical analysis framework to explain the effects of aid inflow on economic growth using time series data of Uganda.

Further, the Uganda Development Plan and vision 2040 have identified structural bottlenecks in the economy that it intends to address in order to accelerate and sustain high economic growth. These include:

i. Dominance of primary commodities over industrial products implying that the rapidly growing new sectors are not contributing significantly to value added exports

ii. Slower than desirable growth in the agricultural and industrial sectors;

iii. New sectors that are not absorbing the rapidly growing labor force

iv. Capital markets that are not effectively intermediating capital.

v. Slow accumulation of core production infrastructure such as energy and transport

Any future external support should be directed to address the above areas for Uganda to achieve high sustained economic growth.

\section{Theoretical and Empirical Literature}

Aid effectiveness has attracted considerable attention in the economic development economics debates. The empirical 
results are mixed as they pose both negative and positive relationships. The emerging literature seems to be that aid does have a positive and negative impact on growth depending on whether its effectiveness has been improved. In the post-war literature by Chenery and Strout [13], aid was central to development discussions within the 'capital bottleneck theories'. Capital scarcity was considered as a major contributory factor to economic backwardness. External finance was seen as a way out of poverty and stagnation by providing developing countries with much needed investment goods. but according to Meier and Stiglitz [54], increased emphasis is being placed on foreign aid to reduce poverty, especially in recent years after the adoption of the Millennium Development Goals (MDGs) at the United Nations Millennium Summit in September 2000.

The two-gap theory, on the other hand, states that investment effort in poor countries in the early stages of development is limited by two constraints. First, due to poverty, these countries are unable to save sufficiently from current income to provide the investment needed to achieve a target rate of economic growth. Second, investment and output are limited by the unavailability of sufficient amounts of imported inputs due to a foreign exchange constraint. The shortage of both domestic savings and foreign exchange to pay for imported materials could be overcome by an inflow of foreign aid. By providing additional resources, economic growth would also rise as the realized incremental investment raises domestic output through higher productive capacity as well as the multiplier effect in the case of underutilized capacity. This has been advanced as one of the most powerful arguments in favour of foreign aid to developing countries.

Siddique at el. [63] investigated the relationship of foreign aid and economic growth using panel data of South and East Asian countries for the period 1995-2013. They used dynamic panel estimation technique and found out significant and robust results that foreign aid promotes the economic growth for the countries in the panel. That aid has positive impact on economic growth in the underdeveloped economies if they have a good monetary, fiscal and trade policies but in the absence of good policies there is negative impact of aid on growth. The developing countries should use aid for development purpose.

Bwire et al, [12] investigated Uganda public expenditure and revenue management reforms from the early 1990s with specific aims of improving budget planning and aligning aid with fiscal priorities. The dynamic relationship between aid and domestic fiscal aggregates was analysed using a Cointegrated Vector Autoregressive model with annual data for 1972-2008 and quarterly data for 1997-2014. They concluded that Aid has been a significant element of long-run fiscal equilibrium, associated with increased tax effort and public spending and reduced domestic borrowing. In addition they found out that Fiscal reforms have improved aid and expenditure management, contributing to improved fiscal performance in Uganda, with lessons for other African countries.

A country would therefore need to raise investment with external capability in order to achieve sustainable economic growth. The view on the demand side driven economic growth suggests that output growth is subject to balance of payment constraints. Success of this goal also depends on establishing a link among investment, exports and savings, i.e. keeping the three engines of growth running. Therefore aid to developing nations is expected to help them take-off and reach the stage of self-sustaining growth. Unfortunately many developing countries especially LDCs remain stagnant and became more aid dependent than were previously. The weaknesses of the policy conditionality designed to deal with external shocks (international agricultural price fluctuations, deteriorating terms of trade, increase in oil prices, etc) have been blamed for the miserable performance. In addition, the macroeconomic impact of foreign aid depends entirely on the interaction of the fiscal, monetary and foreign exchange policies. Continued attraction of foreign aid especially in form of loans may lead to a country failing to honour its obligations to repay the loan. This leads to external debt burden that result from borrowing by developing nations from developed countries. Uganda has accumulated a lot of loans from China of recent and these loans don't include any grant component. The impact of such loans may have a different impact in the country and the very reason why the impact of such should be investigated.

A number of studies have investigated the issue of aid effectiveness for individual aid recipients using time-series data. The impact of foreign aid is likely to be recipient specific as argued by Gounder [32]. He provides evidence that aid has been an important determinant for growth for Fiji and the Solomon Islands. Foreign aid to the island economies is a major source for foreign exchange and resource needs. In his study, he utilised a neoclassical production function to estimate the aid-growth nexus. Components of total aid, such as grant aid, loan aid, technical co-operation, bilateral and multilateral aid flows were also employed to estimate a disaggregated impact of foreign aid in the short run and in the long run. The results showed that bilateral aid, grant aid, and technical co-operation grant have a significant impact on economic growth in Fiji. Lloyd et al. [48] investigated the effectiveness of foreign aid for the case of Ghana. They provide a simple model in which aid contributes to growth through financing government spending (especially public investment). Policy is incorporated via interactive dummies for the period from 1983 (adjustment and post-adjustment). They model growth in private consumption. Exports, aid and public investment all are positively related to long-run growth. These studies found out that aid contributes to longrun growth in private consumption and that policy reform enhanced the effectiveness of aid and concluded that aid can have positive impact on recipient specific country.

Mahembe et. al. [49] examined the causal relationship between foreign aid, poverty, and economic growth in 82 developing countries for the period 1981-2013. They applied dynamic panel data estimation techniques and tested for both panel unit roots and cointegration before employing the panel vector error-correction model (VECM) Granger causality test. They found out that in the short run, there is evidence of (a) a bidirectional causal relationship between economic growth and poverty; (b) a unidirectional causal relationship from economic growth to foreign aid; and (c) unidirectional 
causality from poverty to foreign aid. In the long-run, the study found that (a) foreign aid tends to converge to its longrun equilibrium path in response to changes in economic growth and poverty; and (b) both economic growth and poverty jointly Granger cause foreign aid.

Tendongho [64] studied the increased inflow of aid and its huge potential to steer up the Cameroon's economic growth by bridging its foreign exchange and savings gaps. He investigated whether foreign aid has had any potential benefit on the nation's economic growth. The study included other exogenous variables in the growth equation such as: investment; accumulation of human capital; population growth; the country's economic policy environment and its interaction term with aid; etc. making use of multivariate cointegration techniques with time series data running from 1960 to 2013. It has also made an effort to establish whether aid has been more effective in a period during which more aid was received as compared to the reverse. At the end, the results show a negative relationship between foreign aid and Cameroon's economic growth given the period under investigation, while gross domestic investment has positively affected its growth. No evidence was also found to support the null hypothesis that aid is more effective when received in higher volumes as compared to smaller amounts. The outcome of this study thus suggests that, subsequent aid be geared towards promoting the country's domestic investment given its positive effect and higher potential to boost its economic growth.

Also the study by Tasew [65] and Yohannes [70] found that aid has positive impact on economic growth. Most of the developing countries, especially in sub-Saharan Africa, are faced with low savings and a narrow widening tax base. This problem is coupled by narrow and diminishing export earnings as a result of deteriorating terms of trade. Thus the requisite investments for increased GDP growth are inadequate. In addition Gitaru [29] realized that there was a significant increase in foreign inflows but the economic growth achieved by many Sub Saharan African countries had not been satisfactory. Thus, the actual role of foreign capital inflow has been an area of controversy. He found out that Kenya being one of the major recipients of international aid the country's economy is facing less economic growth and poverty remain inherent for many years.

Karras [43] investigated the correlation between foreign aid and growth using annual data from the 1960 to 1997 for a sample of 71 aid-receiving developing countries. He concluded that the effect of foreign aid on economic growth is positive, permanent, and statistically significant. Mavrotas and Ouattara [52] analyses the effects of aid flows on key fiscal aggregates in Senegal. He utilizes data over the period of $1970-2000$ and primarily focuses on the interaction between foreign aid and debt. He determined three main outcomes that include: a large portion of aid flows, approximately $41 \%$, are used to finance Senegal's debt and $20 \%$ of the government's resources are devoted to debt servicing; that the impact of aid flows on domestic expenditures is statistically insignificant, and that debt servicing has a significant negative effect on domestic expenditure. As a result, he suggests that debt reduction could become a more successful policy tool than obtaining additional loans.

Quartey [60] study focused on innovative ways of making financial aid effective in Ghana. He concluded that mainly multi-donor budgetary support could be successful, but only if the government of Ghana and its partners plan better and coordinate their efforts. He added that the government needs to reduce its debt burden, and not use its aid inflows to service its debt. Ram [61] looked at the issue of poverty and economic growth from the view of recipient country's policies as being the key role in the effectiveness of foreign aid. He disagreed with the widely-acknowledged view that redirecting aid toward countries with better policies leads to higher economic growth and poverty reduction rates. He concluded that evidence is lacking to support the leading belief that directing foreign assistance to countries with desirable policies will increase the impact on growth or poverty reduction in developing countries.

Empirically, Hudson and Mosley [39] and McGillivray, et al. [53] have demonstrated how aid to African countries not only increases growth but also reduces poverty. They also pointed out that continuously poverty, mainly in sub-Saharan African countries, has been one of the targets of the MDGs (Millennium Development Goals) of dropping the percentage of people living in extreme poverty to half the 1990 level by 2015. They concluded that the policy regimes of each aid recipient country, such as inflation and trade openness, influence the amounts of aid received and hence the poverty reduction levels.

Studies have also been done for non-individual economies where groups of economies were looked at for example when examining trends in official aid to Africa over the period 1960 to 2002. Mavrotas and Ouattara [52] emphasized the tremendous decrease in aid over the last decade which had an impact on Africans living in poverty and the African economy as a whole. As a result of the shortfall in aid, the MDGs will be much harder if not impossible to be achieved. He concluded that aid in fact does promote growth and reduces poverty and that it positively impacts on public sector aggregates, contributing to higher public spending and lowers domestic borrowing. In addition, key to note was that the MGDs could not be achieved with development aid alone, but other innovative sources of development finance need to be explored as well. When analysing the effects of foreign aid on the economic growth of developing countries from annual data on a group of 85 developing countries covering Asia, Africa, and Latin America and the Caribbean for the period 1980-2007, Ekanayake and Chatrna [22] found out that that foreign aid has mixed effects on economic growth in developing countries. This was after accounting for regional differences in Asian, African, Latin American and the Caribbean countries, as well as differences in income levels. Also Gonamee at al. [31] addressed directly the mechanisms through which aid impacts growth. Using a sample of 25 Sub-Saharan African countries over the period 1970 to 1997, they determined that foreign aid has a significant positive effect on economic growth. They identified investment as the most significant transmission mechanism. As a result, Africa's poor growth record needs to be attributed to factors 
other than aid ineffectiveness.

According to Harrison [38] and Frankel and Romer [28], Foreign aid inform of trade influences private investment and ultimately economic growth. Based on the neoclassical thinking, openness to trade has advantages like efficiency gains that come with specialization and competition from international trade, embodied technological transfer through imported inputs, economies of scales arising from expanded markets and diffusion of ideas through global interaction but according to Harrison [38], competition arising from openness to trade may discourage innovation by making investment in research and development less profitable underdeveloped domestic industries are exposed to competition from imports while exports are often exposed to very volatile world markets. Although the literature on trade and growth tends to focus on exports, there are two justifications for concentrating on imports as they represent imported technology, capital, and intermediate goods and to some extent are used directly for investment.

Private investment is seen as the engine that drives a country's economy, while public investment provides the necessary infrastructure according to M'Amanja and Morrissey [50]. The two are related since public investment may crowd in investment if it provides the infrastructure to support the private sector or crowd out investment by increasing costs of borrowing public investment itself affects growth either directly, via its productivity, or indirectly via its effect on private investment. Public investment in human capital (health and education), law and order, research and development, and social and economic infrastructure leads to creation of positive externalities which in turn improve the productivity of private investment. Thus, one would expect a positive relationship between public investment and economic growth.

According to Bacha [5], foreign aid is related to investment. Foreign aid could relax any or all of three constraints on investment. The savings constraint arises if, as is likely in low-income countries, domestic savings are insufficient to meet investment requirements, aid which is largely foreign savings, relaxes the constraint. The foreign exchange constraint arises because investment requires imported capital goods and the 'free' foreign exchange available from export earnings may be insufficient; as aid is in the form of foreign exchange, it permits a higher level of capital imports. The fiscal constraint captures the possibility that government behaviour affects private savings and public investment can affect private investment, aid, by financing public investment and reducing the need to raise seignorage revenue to finance a deficit, can relax this constraint.

Easterly [18] noted that large aid inflows induce a sharp and sustained appreciation of the real exchange rate, discourage the expansion of exports particularly nontraditional exports and thereby damage growth prospects of the economy. These concerns have recently come to the notice of a number of well managed low-income countries that have already participated in the debt relief initiative for heavily indebted countries (HIPC) and which are identified as potential fast-track candidates for rapid scaling-up of aid flows, according to the United Nations Millennium Project and these countries include Uganda. These countries face the prospect of higher aid flows in the near future, and definitely with strong pressure from donor nations to see the augmented resources absorbed rapidly. Thus, many question whether this increased aid can generate sufficient returns, in terms of sustained growth, to outweigh the costs of absorbing it, or whether it will contribute to the unravelling of hard-won economic gains secured in recent years are yet to be answered.

Theoretically, according to Harrod-Domar growth model, economic growth is determined by the saving rate, rate of population growth and the incremental capital output ratio. The investment equals savings and anything that increases saving rate, decreases incremental capital output ratio, and decreases in population growth rate will increase economic growth. Therefore, aid inflow can augment domestic savings and increase the rate of investment that leads to a higher economic growth rate. However, history in developing countries has shown that aid largely goes to consumption and crowds out domestic savings and investment. The arguments of augmenting domestic savings was criticized by Griffin and Enos [34] and Weisskopf [67] suggesting that foreign capital inflows would result in a decline in saving propensities resulting into reduced domestic saving rates. Their main contention was that foreign aid was a substitute to domestic savings and a large fraction would be used to increase consumption. In addition, Fafchamps [24], Artadi and Sala-iMartin [4], who belongs to endogenous growth theories, assign an important role to investment both in the short and long term as key for economic growth. They conclude that for aid to increase growth, high quality investment that increases productivity, existence of appropriate policy, democracy and social infrastructure are determinants of the effectiveness of investment as opposed to high investment ratios because they do not necessarily lead to rapid economic growth.

Burnside and Dollar [11] analysed a variety of policy variables and found that the ratio of foreign aid to GDP did not significantly affect growth but foreign aid interacted with policy variables positively and significantly affected growth. They modified the neoclassical growth model to show how twisted policy may affect economic growth in developing nations. From the neoclassical growth theory, the marginal return to investment in poor countries is high; thus countries tend to grow faster when their capital accumulation is rising. However they argued that with a subsistence consumption, constraint and imperfect international capital markets, poor nations will tend to grow slowly despite a high marginal return to investment. In this context, foreign aid can accelerate growth rates in the transition to a steady state. Also various institutional and policy distortions can lower the return to capital and reduce the transitional growth rates. To test the interactive effect of aid and economic policy on growth, Burnside and Dollar [11] incorporated aid into the Barro [7] and Barro and Sala-i-Martin [8] models plus the interactive term for aid variable and policy index which were endogenised in order to tackle the simultaneity issue.

While aid is assumed to have a positive impact on growth if the appropriate policies are in place, there is another 
perception that aid can do more harm than good to a recipient nation when the level of aid is high (greater than $30 \%$ of GDP). This view has been recognized in the analysis of the two gap model by Durbarry et al. [17], where it is referred to as the "absorptive capacity constraint". The view is that high aid inflows, which exceed those which can feasibly be used in profitable investment, are likely to be allocated to unprofitable investment or consumption. This is the issue of fungibility that leads to underutilization of foreign aid. If a large amount of aid is allocated on non-productive investment, it will have a negative effect on growth as concluded by Griffin an Enos [34], Mosley [56] and Lavy and Sheffer [43].

Furthermore, Lensink and White [45] applied an endogenous growth model which exhibits a negative return to aid at higher levels. The level of technology is endogenized in the system and depends on the level of aid flow. They conclude that there is a certain level of aid flow which turns the growth rate of output negative. The implication of this analysis is that there exists an aid "Laffer Curve". For small levels of aid, there is a positive relationship between aid and economic growth, while at higher levels of aid, aid negatively affects economic growth. They emphasize the stability rather than the level of aid inflow as the key for economic growth. They added that if the recipients are unsure of whether they would achieve the policy targets required to trigger a tranche of aid, uncertainty may have similar effects on investment decisions and on the broader fiscal behaviour of government. Investment and aid have a strong linear relationship and this creates a multicollinearity problem. In addition there are some variables associated with new development policies growth which are not included in the model.

Easterly [18] established that the link between foreign aid and investment is negative and concludes that there is practically no support of the simple two-gap approach. However, Easterly's result on the relationship between investment and growth is a clear outlier, when the general empirical growth literature is considered. Practically all studies assessing the empirical relevance of potential growth determinants have found the investment rate to be one key influence of economic growth. Levine and Renelt [46] found the investment rate to be one of variables to be robust to the inclusion or exclusion of other variables. A similar result was obtained in the less stringent robustness test of Sala-i-Martin [62] for both equipment investment and non-equipment investment.

Also Hadjimichael et al. [37] using a sample of 31 subSaharan Africa countries found that aid affects the growth rate, as do a number of policy variables (government investment, human capital, population growth, terms of trade, real effective exchange rate, and the budget deficit. Levy [47], Mosley [56] and Devarajan, et al., [15], suggest that foreign aid in Sub-Saharan Africa (SSA) is used to cover budget deficits and yet the deficit keep on increasing each year. As a result, it calls for more aid to handle the deficit with increased debt burden and reduced economic growth. But Feyzioglu et al. [26] has claimed that unfortunately, with fiscal problems and change in political focus by the donor community, the foreign aid taps seem to be running dry.
Elbadawi [23] argues that in Sub-Saharan Africa foreign aid causes exchange rate appreciation thereby dampening growth of exports and economic growth. Most studies before 1980 like Gupta and Islam [36] and Griffin and Enos [34] found a negative impact of foreign Aid on economic growth. However, Papanek [57] who disaggregated capital flow into public foreign aid, private capital inflow and other flows, his results over turned the negative results of Griffin and Enos [34], Voivodas [66] obtained negative impact of aid on economic growth when he analysed data for 22 less developed countries for a period of thirteen (13) years. Also Gupta [35] and Gupta and Islam [36] showed that if indirect effects are included, the estimates of a negative effect can be overturned.

Mosley [56] using a simultaneous equations model found a week negative correlation between growth and aid, although for the poorest countries in his sample found a positive significant relationship. He used the current account deficit to draw conclusions regarding foreign aid effects which makes his analysis incomplete. Apart from Mosley [56], the rest used a single equation for their analysis. The poor results of the aid growth coefficients might have been also caused by poor quality of data and the single equation. To improve the estimation of the aid-growth coefficient, many studies of aid effectiveness have incorporated a number of factors accounting for policy and institutional changes into the growth-aid model. As a result the coefficient of the aidgrowth variable improved as evidenced by Dowling and Hiemenz [14] who found a positive relationship between aid and growth in their studies for Asian countries. They used pooled data for 13 countries and controlled policy variables like trade, finance and government intervention.

Feeny [25] investigated whether aid effectiveness depends on the level of governance. He concluded that aid was more effective during World Bank adjustment program. The previous literature had focused exclusively on the role of policy. This is important to Uganda where corruption and conflicts cited as important factors that have affected investment, hampered growth and undermined development. Mauro [51] tests for the effects of corruption on investment and found out that payment of bribes in order to obtain an investment licenses acts as a tax on investment and reduces the incentive to invest. He uses a bureaucratic efficiency index and an index of political stability to measure the extent of corruption. He finds that corruption lowers private investment and thereby reduces economic growth. He hypothesizes that the cost of setting up businesses and the ability of investors to reap returns from their investments, varies considerably across countries. He predicts that a country that attracts investments in the form of capital for businesses, technology transfer from abroad and skills from individuals will be one in which: (a) the institutions and laws favour production over diversion; (b) the economy is open to international trade and competition in the global marketplace; and (c) the economic institutions are stable. He states that a good infrastructure provides an environment which encourages investment, the acquisition of skills, invention and technology transfer.

Alesina et al [2] construct a democracy index DEM taking 
values between 1 and 3 based on information on electoral systems. 1 was for democratic regimes (countries with free competitive general elections with more than 1 party running), 2 for mixed democratic and authoritarian features (countries with some form of elections but with severe limits in the competitiveness of such ballots) and 3 for authoritarian regimes (countries in which their leaders are not elected). This is also adapted for this study. According to Husain [40], the external resources are divided in two categories, the resources which have stable, sustainable and positive effect on economic growth and are within the policy control of the domestic authorities which include export of goods and services $(X)$ and the Second, foreign aid and external borrowings that are found to be volatile, and ODAY, which is under the control of external policymakers and their contributions to economic growth.

The study follows the methodology of Gomanee et al. [31] by using a generated regressor technique to address the problem. A preliminary regression is estimated using investment as the dependent variable and aid is included as an explanatory variable together with other potential determinants of investment. These control variables include economic growth, inflation and the availability of credit, governance and policy. The variable INVRESS is constructed which represents the part of investment which is not attributed to foreign aid. It is constructed using the residuals from a bivariate regression in which investment is regressed on aid. The variable INVRESS is then substituted for INVY in the regression. This ensures that the model is correctly specified, and that there is no double counting and the coefficient on the aid variable is unbiased.

Babyenda [6] investigated the impact of foreign aid on Uganda's economic growth for the period 1980 - 2012 using secondary time series. He based his model on the production function where foreign aid enters into the production function as one of the inputs. He used a single equation error correction model. The study found out that foreign aid has no significant impact on Uganda's economic growth while inflation significantly negatively affects the process of economic growth in Uganda. He recommended that the government of Uganda should find alternative sources of funding since foreign aid has no significant impact on Uganda's growth process and that the government of Uganda should also strive hard to maintain economic stability in the country by controlling the rate of inflation. This study is using data since 1970 - 2017. In addition the model for this study looks at labor and capital as in put and has variables that include Investments, foreign aid, Exports, effective labor, dummy variable for the civil war and the democratic process of Uganda. The author considered only GDP, Foreign aid and inflation for which the labor side was not included.

\section{Methodology and Data Analysis}

\subsection{Theoretical Framework}

The empirical model used in this study is motivated by an endogenous growth model. Following Jones [42], the aggregate production function is provided by:

$$
Y=I K^{\alpha}(A L)^{1-\alpha}
$$

Where I denote the influence of an economy's infrastructure on the productivity of its inputs, $\mathrm{K}$ is capital, A is a measure of technology, $\mathrm{L}$ is labour and $\alpha$ is a parameter between 0 and 1. For the endogenous growth models, changes in the rate of investment and changes in government policies can impact on the long run rate of growth. This is an important feature of the model estimated as both the short and long run determinants of growth are estimated. The model emphasizes the infrastructure of an economy (I), relating to the government policies and institutions which make up the economic environment as an important determinant of growth.

Three variables are used to proxy the economy's infrastructure as guided in the theoretical model: $\mathrm{X}$ is the ratio of exports of goods and services to GDP; DEM is an index of governance; ODAY, the focus of this study, is the ratio of foreign aid to GDP. Some cross-country studies have recognized that including both aid and investment variables as regressors introduces a problem of double counting since some part of investment will be funded by aid. The problem of double counting will lead to a biased (downward) coefficient on the aid variable. Therefore, an aid variable is included while omitting the investment variable. However, omitting the investment variable will result in model misspecification and a biased coefficient on the aid variable. The coefficient will again be biased downwards since only a fraction of foreign aid is provided for investment purposes.

\subsection{The Model}

From Husain [40], the link between economic growth and foreign aid is developed using a pure production function theory. Assume that real gross domestic product (GDP) of Uganda is:

$$
Y=F(X)
$$

Where $Y$ is the real GDP per capita, $F$ is the transformation function associating $Y$ and $X, X$ is the vector of explanatory inputs. Assuming a multiplicative aid-trade-augmented production function and that capital $(K)$, labour $(L)$, foreign aid $(A)$ and exports $(X)$, according to Amavilah [3] equation (2) becomes:

$$
Y=\theta K^{\alpha}{ }_{L}^{\beta} X^{\gamma} \gamma_{A}^{\mu} e^{\delta}
$$

The exports are included in the conventional production function because exports allow countries to specialize in the production of commodities in which they have comparative advantage. Exports growth facilitates the exploitation of scale economies and allows for increased capacity utilization and encourages efficiency through specialization in accordance with the principles of comparative advantage. In addition, the export sector is assumed to generate positive externalities. 
Edwards [19] points out that exports affect economic growth positively through increases in total factor productivity like the foreign aid is included in the conventional production function and supported be Gounder [32], Amavilah [3] and Burke, et al.[9] among others. Burke, et al. [9] and Ahmed and Hamdani [1] recommends the breaking up the total capital stock $(K)$ into domestic capital $\left(K_{d}\right)$ and foreign capital $\left(K_{f}\right)$ i.e., $K=K_{d}+K_{f}$. Therefore, equation (3) becomes,

$$
Y=\theta K_{f}^{\alpha} L^{\beta} X^{\gamma}{ }_{A}^{\mu} e^{\delta}
$$

and equation (4) can be written in Log-Linear form as shown in equation 5 below:

$$
\operatorname{Ln} Y=\operatorname{Ln} \theta+\alpha \operatorname{Ln} K_{d}+v \operatorname{Ln} K_{f}+\gamma \operatorname{Ln} X+\beta \operatorname{LnL}+\mu \operatorname{Ln} A+\delta
$$

\subsection{Data Source and Type}

This study uses time series data for the period 1970-2017 to investigate the effects of aid on growth in Uganda. Estimation is carried out using the Autoregressive Distributed Lag (ARDL) approach to cointegration, proposed by Pesaran and Shin [58]. The study has applied Burnside and Dollar [10] model in constructing two policy indices to control monetary policy and fiscal policy. One of the variables is inflation which is used as a measure of monetary policy and the other is government consumption (relative to GDP) to measure the fiscal policy. Recipients with good policy are assumed to have low inflation and large government consumption.

The study used secondary data that was time series in nature for the period 1970-2017. The growth rate of population is used as a proxy for the growth rate of the labor force. The data on population are from the World Bank, World Development Indicators database. The data on foreign aid are from the Organization for Economic Corporation and Development (OECD), Data on real GDP per capita, foreign aid inflows per GDP and exports per GDP were obtained from the World Development Indicators databases of the World Bank online and various issues of Uganda Statistical Abstracts. The economic growth rate is measured in this study as the growth of real GDP per capita in constant (2010) The data on real GDP are from the World Bank, World Development Indicators database. The investment/GDP ratio is used as a proxy for the growth rate of the capital stock. Gross fixed capital formation as a share of GDP is used to represent investment/GDP ratio. The data on foreign aid/GDP are from the World Bank, World Bank. Stat online database and Uganda statistical abstract, labour (L) is the growth rate of effective labour force (GLE) ${ }^{1}$ as shown in equation 7 . The growth rate of effective labour force is based on Xayavong [69] and it is defined as follows:

$$
\begin{gathered}
L E_{t}=S E_{t} \frac{L F_{t}}{P O P_{t}} \\
G L E_{t}=\frac{L E_{t}-L E_{t-1}}{L E_{t-1}}
\end{gathered}
$$

1 The effective labor force is computed from $G L E_{t}=\frac{L \dot{E}_{t}}{L E_{t}}$.
Where $L E_{t}$ is the effective labour force, $S E_{t}$ is the total number of students enrolled for secondary and tertiary levels, $L F_{t}$ is the labour force, $P O P_{t}$ is the total population and $G L E_{t}$ is the growth rate of the effective labour force. $L F_{t}$ is used because of lack of employment data in Uganda. Foreign aid as a share of GDP $(O D A Y)^{2}$ is used. Edwards and Tabellini [20] and Fosu [27] argue that political instability is expected to exert negative impacts on growth; $\mathrm{DEM}^{3}$ is an index of governance, taking values between 1 and 3 based on information on electoral systems. 1 for democratic regimes (countries with free competitive general elections with more than 1 party running), 2 for mixed democratic and authoritarian features (countries with some form of elections but with severe limits in the competitiveness of such ballots) and 3 for authoritarian regimes (countries in which their leaders are not elected). and to account for political instability a dummy variable $\mathrm{DUM}^{4}$ taking value of one for the period 1985-2017 and zero for 1970-1985. This is the period when Uganda faced wars external and internal wars and the resulting model is as follows:

$$
Y_{t}=\beta_{0}+\beta_{1} L I N V Y+\beta_{2} D U M_{t}+\beta_{3} L A_{t}+\beta_{4} L O D A Y+\beta_{5} L E Y_{t}+\beta_{6} D E M_{t}+\varepsilon_{t}
$$

\section{Empirical Results and Discussion}

This section focuses on the effects of foreign aid on the economic growth and the aid transmission mechanisms for growth of Uganda. Time series secondary data were used for the analysis. The secondary data were obtained from such publications as World Bank Digest of Statistics, Uganda Central Bank, statistical abstracts, Background to the budget and International Financial Statistics. Since the study makes use of time series secondary data, temporal properties of the variables in the model were checked by use of the unit root tests in order to determine the stationarity of the variables. The process of unit root test is therefore important to determine whether or not the variables contain a trend and whether that trend is deterministic or stochastic. It is also a preliminary step in testing for cointegration and causality. It was conducted to verify the stationarity properties (absence of trend and long-run mean reversion) of the time series data so as to avoid spurious regressions. Time series that diverge away from their mean over time are said to be non-stationary. Therefore, the classical estimation of variables with this relationship most times gives misleading inferences or spurious regression. To overcome this problem of nonstationarity, the analysis of time series data has increasingly

2 Official Development Assistance (ODA) flows comprise of contributions of donor government agencies to developing countries. ODA is the flow of official financing with a purpose of promotion of economic development and welfare of developing countries, which are concessional in character with a grant element of at least 25 percent (using a fixed 10 per cent rate of discount). It is normally targeted to the poorest countries and classified into two types: grant and loan aid. 3 1970-1971 takes a value of 1, 1972-1979 takes value of 3, 1980-1984 takes a value of 2, 1985 takes a value of 3, 1986-1995 takes a value of 2 and 1996-2017 takes a value of 1 .

4 Section 2.5 gives details of this variable. 
moved towards the issue of cointegration. The reason being that, cointegration is a powerful way of detecting the presence of steady state equilibrium between variables. Cointegration has become an over-riding requirement for any economic model using non-stationary time series data. If the variables do not cointegrate, then we have the problems of spurious regression and the results therein become almost meaningless. On the other hand, if the variables do cointegrate then we have cointegration.

The Autoregressive Distributed Lag (ARDL) cointegration technique or bound test of cointegration by Pesaran and Shin [58] and Pesaran et al. [59] and Johansen and Juselius [41] suggest that cointegration techniques is the solution to determining the long run relationship between series that are non-stationary, as well as re-parameterizing them to the Error Correction Model (ECM). This gives the short-run dynamics and long run relationship of the underlying variables. Although ARDL cointegration technique does not require pre-testing for unit roots, to avoid ARDL model crash in the presence of integrated stochastic trend of I (2), the unit root test was carried out to know the number of unit roots in the series under consideration. Diagnostic tests such as F-test, Akaike, Schwarz criteria test, Jarque Bera test, BreuschGodfrey Serial Correlation LM Test, White Heteroskedasticity Test and Ramsey RESET Test were applied to determine the sturdiness and significance of the empirical model.

\subsection{Unit Root Test}

Many economic and financial time series exhibit trending behaviour or non-stationary in the mean. Economic Variables like exchange rates, levels of macroeconomic aggregates like real GDP, investment and others have been found to have trends. An important econometric task is determining the most appropriate form of the trend in the data. In ARMA modelling the data must be transformed to stationary form prior to analysis. If the data are trending, then some form of trend removal is required. Unit root tests were used to determine if trending data should be first differenced or regressed on deterministic functions of time to render the data stationary. Economic and finance theory often suggests the existence of long-run equilibrium relationships among non-stationary time series variables. If these variables are I (1), then cointegration techniques can be used to model these long-run relations. Therefore, pre-testing for unit roots is often a first step in the cointegration modelling. In this study a unit root test was conducted on the variables using the Augmented Dickey-Fuller (ADF) test to examine each of the variables for the presence of a unit root.

The unit root test was conducted on variables that included, LGDPY, LEY, ODAY, DEM, LINVY, DUM, and L and verified that all the series are integrated of order one as shown in table 1, where LGDPY=Real per capita income, LINVY $=$ Total investment residual, ODAY $=$ Official Development Assistance per GDP, LEY=Exports per GDP, $\mathrm{LA}=$ Labour growth, DUM=Dummy variable for political instability.

Since the ADF test can handle both first order and higher order auto-regressive processes, the first difference in lags was included in such a way that the error term is distributed as white noise. The number of augmenting lags (p) was determined by minimizing the Schwartz Bayesian information criterion /minimizing the Akaike information criterion/lags were dropped until the last lag was statistically significant. The use of data characterized by unit roots may lead to serious error in statistical inference as stated before. If time series variables are non-stationary and co-integrated, at any point in time the variables may drift apart, but there will always be a tendency for them to retain a reasonable proximity to each other. In our model, the relationship that tends to tie together the non-stationary variables in the long run is because they attain equilibrium in the long run. The ADF test results for both in level and at the first difference with intercept and no trend were determined. From table 1, the conclusion is that all the variables under study are integrated of order one, implying that all the series are nonstationary and the standard regression analysis may produce spurious results. As variables were found to be non-stationary in levels but stationary after first difference, it confirms that the hypothesis of a unit root cannot be rejected in all variables in levels. The hypothesis of a unit root is rejected in first differences at 0.05 level of significant which indicates that all variables are integrated of degree one.

Table 1. Unit Root Test.

\begin{tabular}{llllll}
\hline \multirow{2}{*}{ Variable } & \multirow{5}{*}{ Stat } & \multicolumn{3}{l}{ ADF Tests } & \\
\cline { 3 - 5 } & & $\mathbf{1 \%}$ & $\mathbf{5 \%}$ & $\mathbf{1 0 \%}$ & \\
\cline { 2 - 5 } Oritical Values & $\mathbf{1 \%}$ & \\
\hline \multirow{2}{*}{ LGDPY } & -2.076 & -3.606 & -2.937 & -2.607 & Non stationary at I (0) \\
& -4.702 & -3.61 & -2.939 & -2.608 & Stationary I (1) \\
\multirow{2}{*}{ LODAY } & -1.675 & -3.606 & -2.937 & -2.607 & Non stationary at I (0) \\
& -5.532 & -3.61 & -2.939 & -2.608 & Stationary at I (1) \\
LNVY & -1.627 & -3.606 & -2.937 & -2.607 & Non stationary at I (0) \\
& -8.18 & -3.61 & -2.939 & -2.608 & Stationary at I (1) \\
LEY & -1.893 & -3.607 & -2.938 & -2.607 & Non stationary at I (0) \\
& -6.591 & -3.611 & -2.94 & -2.608 & Stationary at I (1) \\
LA & -1.553 & -3.606 & -2.975 & -2.627 & Non stationary at I (0) \\
& -3.997 & -3.708 & -2.98 & -2.629 & Stationary at I (1) \\
DUM & -1.513 & -3.606 & -2.937 & -2.607 & Non stationary at I (0) \\
& -4.748 & -3.61 & -2.939 & -2.608 & Stationary at I (1) \\
DEM & -1.777 & -3.711 & -2.981 & -2.63 & Non stationary I (0) \\
& -4.307 & -3.738 & -2.992 & -2.636 & Stationary at I (1) \\
\hline
\end{tabular}

Source: Author's computations.

The Augmented Dickey-Fuller (ADF) unit root tests can omit the possibility of a unit root with break. If a break exists under the unit root null, two undesirable results can follow. First, these endogenous break unit root tests will exhibit size distortions such that the unit root null hypothesis is rejected too often. It is likely that a conclusion can be made that a time series is stationary with break when in fact the series is non-stationary with break. As such, "spurious rejections" might occur and more so the magnitude of the break increases. It is therefore necessary to confirm by undertaking a unit root test with structural breaks because the first step of 
the empirical analysis involves determining the order of integration.

\subsection{Structural Breaks}

The testing of the unit roots of a series is a precondition to the existence of cointegration relationship, therefore it is important to make the best conclusions about series being stationary or not. Originally, the Augmented Dickey-Fuller [16] test was widely used to test for stationary. However, Perron showed that failure to allow for an existing break, which may be the change in the series as a result of some unique economic events, leads to a bias that reduces the ability to reject a false unit root null hypothesis. To overcome this, a known or exogenous structural break is considered in the test. All the variables were plotted on a graph and it showed a displacement at 1985 and this is the time when Uganda was ending the civil war. A CUSUM test was conducted as indicated in figure 1 below. The fluctuations started in 1985 and the parameters start being unstable. The Chow break point stability test on the parameters is shown in table 1 . The CUMSUM in figure 1 was calculated for the model to detect the presence of structural instability and model misspecification. All estimations were carried out using eviews 9. From table 3, the bound cointegration test rejects the null of no cointegration because the computed F-statistic is much greater than the upper bound of the tabulated F-statistic. After finding the evidence of cointegration between the variables specified above, the long run and short-run relationships were estimated using Autoregressive Distributed Lag (ARDL) approach.

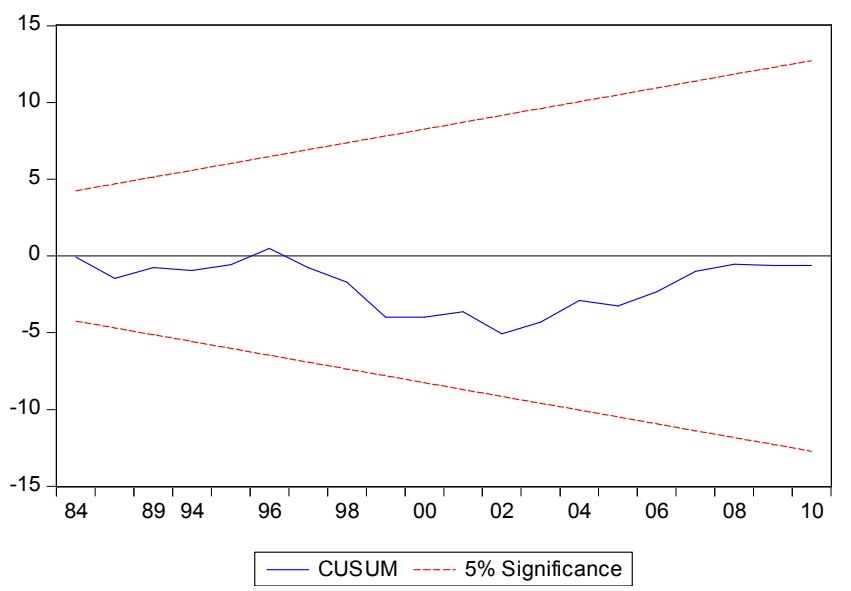

Figure 1. CUSUM Test.

The Chow test is most commonly used in time series analysis to test for the presence of a structural break. The chow test is often used to determine whether the independent variables have different impacts on different subgroups of the population. However, an important limitation of the Chow test is that the break date must be known a priori. In this study, the data was graphed and a spike in the data was seen in 1985. The null hypothesis that there is no break at the specified breakpoints is rejected. This implies that the model can be improved by adding a dummy variable at the break point. As a result, DUM85 is included in the model. DUM85 has a value of 0 for 1970-1985 and value of 1 for 1986-2017.

Table 2. Chow Breakpoint Test.

\begin{tabular}{llll}
\hline \multicolumn{4}{l}{ Chow Breakpoint Test: 1985 } \\
\hline \multicolumn{4}{l}{ Null Hypothesis: No breaks at specified breakpoints } \\
\hline F-statistic & 2.658 & Prob. F $(8,12)$ & 0.0618 \\
Log likeli ratio & 28.55 & Prob. Chi- (8) & 0.0004 \\
Wald Statistic & 21.26 & Prob. Chi- (8) & 0.0065 \\
\hline
\end{tabular}

Source: Author's computations.

\subsection{Cointegration Test}

Having established the assumptions for ARDL approach that include, data must be free from autocorrelation, Data must be free from heteroscedisty, data must be normally distributed, all variables must be I (0) or I (1) or mixture of level and first difference. A cointegration test based on the ARDL procedure is employed by for Uganda using annual data over the period 1970-2017. The number of lags on the first-differenced variables was selected using Akaike Information Criterion (AIC). Initially, these were selected by testing down using general-to specific methodology. The final lag was then selected when the estimated equation satisfied all the diagnostic checks and the CUSUMSQ test of stability. Testing for cointegration is a necessary step to establish if a model empirically exhibits meaningful long run relationships.

Table 3. Results of ARDL Cointegration Test-bound test.

\begin{tabular}{|c|c|c|}
\hline \multicolumn{3}{|c|}{ ARDL Bound Test } \\
\hline \multicolumn{3}{|c|}{ Null Hypothesis: No long-run relationships exist } \\
\hline Test Statistic & Value & $\mathrm{k}$ \\
\hline F-statistic & 32.65 & 6 \\
\hline \multicolumn{3}{|c|}{ Critical Value Bounds } \\
\hline Significance & I0 Bound & I1 Bound \\
\hline $10 \%$ & 2.53 & 3.59 \\
\hline $5 \%$ & 2.87 & 4 \\
\hline $2.5 \%$ & 3.19 & 4.38 \\
\hline $1 \%$ & 3.6 & 4.9 \\
\hline
\end{tabular}

Source: Author's computations.

If it failed to establish the cointegration among underlying variables, it becomes imperative to continue to work with variables in differences instead. However, the long run information will be missing. There are several tests of cointegration, other than Engle and Granger [21] procedure, among them is; Autoregressive Distributed Lag cointegration technique or bound cointegration testing technique. This becomes the focal point of this study. On the basis of this criterion, four lags were selected to carry out cointegration test in Table 3.

The presence of long run relationships in the model was tested. The results of the bound test indicate that the calculated F statistics 32.65 surpassed the upper bound critical value for any significance level. It means there is a long-term equilibrium among the considered variables, in the examined period. The null hypothesis of no cointegration is rejected. The ARDL procedure starts with determining an 
appropriate lag order (p) in equation (8). For this purpose, the Akaike Information Criterion (AIC) indicating that $p=4$ is the most appropriate lag length for the foreign aid inflow. The short run and long-run equation were estimated using the optimal ARDL $(5,1,2,0,1,1,0)$ order, according to the Akaike Information Criterion.

\subsection{Estimation Results and Discussion}

Table 4 reports the short run while table 5 reports the long-run estimates for various types of aid-growth nexus. The estimated ARDL equation passes all the diagnostic tests of stability. The estimation results from the model reveal that investment (LINVY) has a positive sign and significant in the short run which is consistent with the neoclassical investment theory which stipulates that greater output enhances investment. This domestic investment is a combination of public and private investment. According to Ghani and Din [30], because of the dominant share of public investment in total investment, the inefficient and non-productive nature of public investment might not have contributed to the overall positive impact of total investment on growth. The index for governance (DEM) was statistically significant with a negative sign when lagged once and positive without lag. The effective Labor force (LA) was statistically significant and negative at $1 \%$ level of significance in the short run but positive and significant at $5 \%$ in the long run. There is a high level of the share of non-productive labour in total labour force in Uganda that might have affected economic growth in the short run. There is also the presence of low quality and unskilled labour force in Uganda which might have contributed to the negative contribution of labor. The export (LEY) is positive and statistically significant. In the short run investments boost output. The foreign aid inflow is significant but negative at $1 \%$ level. Implying that in the short run aid inflow reduced output probably due to the reconstruction period after the war where almost all inputs were imported. The political instability (DUM) was positive and statistically significant probably the external war of 1978 and the internal civil wars of the 1980s might not have affected investment growth through the decline in total factor productivity as argued by Gounder [32].

The index for governance (DEM) was positive and statistically significant at $1 \%$ level but when lagged once was statistically significant with a negative sign. The Labour force (LA) was statistically significant and negative. The overall contribution of labour force (LA) is negative and significant at 5 per cent level in the short-run.

Table 4. Short Run ECM Representation of the ARDL.

\begin{tabular}{llll}
\hline \multicolumn{2}{l}{ Dependent Variable: LGDPY } & & \\
\hline Variable & Coefficient & Std. Error & t-Statistic \\
\hline D (LGDPY (-1)) & $0.582^{* * *}$ & 0.141 & 4.129 \\
D (LGDPY (-2)) & 0.096 & 0.141 & 0.682 \\
D (LGDPY (-3)) & -0.131 & 0.127 & -1.021 \\
D (LGDPY (-4)) & 0.271 & 0.172 & 1.578 \\
\hline
\end{tabular}

\begin{tabular}{llll}
\hline \multicolumn{2}{l}{ Dependent Variable: LGDPY } & & \\
\hline Variable & Coefficient & Std. Error & t-Statistic \\
\hline D (LODAY) & $-0.276^{* * *}$ & 0.047 & -5.868 \\
D (DEM) & $0.308^{* * *}$ & 0.06 & 4.886 \\
D (DEM (-1)) & $-0.240^{* * *}$ & 0.067 & -3.59 \\
D (DUM) & $0.399^{* *}$ & 0.165 & 2.422 \\
D (LA) & $-0.06^{* * *}$ & 0.017 & -3.316 \\
D (LEY) & $0.350^{* *}$ & 0.134 & 2.615 \\
D (LINVY) & $0.323^{* * *}$ & 0.079 & 4.102 \\
D (@TREND ()) & $0.041^{* *}$ & 0.012 & 3.351 \\
ECT (-1) & $-0.855^{* * *}$ & 0.174 & -4.923 \\
\hline
\end{tabular}

Note: Ramsey RESET test \{residual squares\}: F $(6,38)=0.057$; Breusch Pagan heteroscedasticity: Chi-square (6) $=0.6526$; Normality test: Chi-square (2) $=3.494$; D-difference.

$*, * *, * * *$ denotes statistical significance at $10 \%, 5 \%$ and $1 \%$ respectively Source: Researcher's Computations.

It is probably because of higher levels of share of nonproductive labour in total labour force in Uganda that might have affected economic growth in the short run. There is also the presence of low quality and unskilled labour force in Uganda which might have contributed to the negative contribution of labor. Brain drain can also be another reason of the negative effect of labour force in the short run. The speed of adjustment coefficient (ECT) in table 4 possesses the expected negative sign and highly significant at 1 percent level. This indicates that 85.5 percent of the previous period deviations are eliminated in the current period. The error correction coefficient is negative which confirms the long-run relationship between the variables. Its value -0.855 indicates a rapid adjustment process, with almost more than half of the whole disequilibrium of the previous year's shock adjusting back to the long-run equilibrium in the current year. Diagnostic tests for serial correlation, functional form, parameter stability, normality and heteroscedasticity were conducted and the results are shown in Table 4 . The results also indicate that there is no suspicion of multicolinearity among variables as functional form of the model is well specified and there is no evidence for heteroscedasticity as well. The foreign aid inflow (ODAY) had a negative sign in the short run and very significant at $1 \%$ level. The negative sign might be because of the aid utilization. Most of it might have been used on consumption goods rather than capital goods. This implies that instead of relying on foreign aid preference should be given to attract foreign direct investment and boost exports. These benefits are more stable than the temporary benefits of foreign aid as the magnitude of exports promoted is larger and sustainable. More employment is created and local resources utilized. Therefore, much attention should be put on the export growth than on attracting more foreign aid. The lagged variable for LGDPY lagged once, is positive and statistically significant at $1 \%$ level of significance in the short run implying that output for the previous period affected positively the current output. 
Table 5. Long Run Model Representation of the ARDL Model.

\begin{tabular}{llll}
\hline Variable & Coefficient & Std. Error & t-Statistic \\
\hline LODAY & $-0.244^{* * *}$ & 0.063 & -3.88 \\
DEM & $0.536^{* * *}$ & 0.119 & 4.51 \\
DUM & $0.467^{* *}$ & 0.219 & 2.13 \\
LA & $0.446^{* *}$ & 0.169 & 2.644 \\
LEY & $0.497^{* *}$ & 0.170 & 2.885 \\
LINVY & 0.143 & 0.088 & 1.632 \\
C & $2.820^{* * *}$ & 0.415 & 6.803 \\
@TREND & $0.048^{* * *}$ & 0.009 & 5.350 \\
\hline
\end{tabular}

$*, * *, * *$ denotes statistical significance at $10 \%, 5 \%$ and $1 \%$ respectively.

Source: Researcher's Computations.

A long run relationship between the variables was supported and parameters estimated using the ARDL method. The lag length was set at four periods on all variables in the general ARDL equation which is standard practice when using annual data. The model was then tested down using the Schwarz Bayesian Criterion (SBC) for lag selection. The final estimated equations passed diagnostic tests for serial correlation, functional form, normality of residuals and heteroskedasticity.

As shown in Table 5, the presence of significant lags of the respective variables evokes several questions. It shows that the long run equilibrium is underpinning a more complicated dynamic structure and the possible persistence of autocorrelation in the error term $\varepsilon_{\mathrm{t}}$ would become critical for correct interpretation of the speed of adjustment towards equilibrium coefficient. Fortunately, the respective autocorrelation coefficient $(0.03)$ proved to be not statistically significant and autoregressive polynomial distributed structure given seems to explain the long term equilibrium dynamics well.

The comprehensive long-term influence of the exports (LEY) on LGDPY seems to be statistically significant at 5\% level and positively influencing output. The foreign aid inflow is negatively influencing output. If foreign aid inflow increases by $1 \%$ it would invoke a reduction of 0.244 in the output (LGDPY). Therefore aid inflow does not increase output in short and long run.

The coefficient on the dummy variable (DUM) is positive and significant in the long run. In certain perspective war can be beneficial for economic growth because War leads to higher government spending; higher employment and can therefore provide a boost to domestic demand, economic growth and help reduce unemployment in the long run. Governments have used this excuse to borrow much more than it could in peaceful times. War can provide a temporary boost to domestic demand but it is important to bear in mind the cost of war in the long run. In particular the opportunity cost of military spending, the human cost of lost lives, the cost of rebuilding after the devastation of war cannot be handled in the long run. The wars of the 1978 and that of the 1980s destructed the economic infrastructure and production that led to the reduced in economic growth. The coefficient of investment (LINVY) is positive and not statistically significant in the long run. This result indicates that investment has not contributed to economic growth in Uganda.

\section{References}

[1] Ahmed, E. and A. Hamdani (2003): The Role of Foreign Direct Investment in Economic Growth. Pakistan Economics and Social Review 41: 1\&2, 29-43.

[2] Alesina, A., S. Ozler, N. Roubini and P. Swagel. (1992): Political instability and Economic growth. NBER Working Paper no. 3478.

[3] Amavilah, A. V. (1998) German Aid and Trade versus Namibian GDP and Labour Productivity. Applied Economics 30, 689-695.

[4] Artadi, E. V and Sala-i-Martin, X (2003), The Economic Tragedy of the XXth Century: Growth in Africa', Cambridge, MA: NBER Working Paper Series WP9865.

[5] Bacha, E. L. (1990), 'A Three-gap Model of Foreign Transfers and the GDP Growth rate in Developing Countries, Journal of Development Economics, 32: 279-296.

[6] Babyenda Peter (2014): Foreign Aid and Economic Growth in Uganda, Unpublished, School of Economics, Makerere University Kampala.

[7] Barro R. (1991): Economic growth in a cross section of countries, Quarterly Journal of Economics, 106.

[8] Barro R. and Sala-i-Martin X. (1995): Economic growth, New York: McGraw-Hill London School of Economics.

[9] Burke, P. J. and F. Z. Ahmadi-Esfahani (2006): Aid and growth: A study of South East Asia, Journal of Asian Economics. 17: 350-362.

[10] Burnside C. and Dollar D. (2001): Aid, policies, and growth. American Economic Review 90.

[11] Burnside C. and Dollar D. (1997): Aid, Policies, and Growth, Policy Research Working Paper No. 1777, World Bank.

[12] Bwire Thomas, Tim Lloyd \& Oliver Morrissey (2017): Fiscal Reforms and the Fiscal Effects of aid In Uganda, The Journal of Development Studies. 53 (7).

[13] Chenery, H. and A. Strout (1966): Foreign assistance and economic development, American Economic Review 56.

[14] Dowling, J. M. and U. Hiemenz (1982): Aid, Savings, and Growth in the Asian Region, Economic Office Report Series 3, Asian Development Bank.

[15] Devarajan, S., V. Swaroop, and Heng-fu Zou. (1998): The composition of public expenditure and economic growth." Journal of Monetary Economics 37.

[16] Dickey, D. A and Fuller, W. A. (1979): Distributions of the Estimators for Autoregressive Time Series with a Unit Root, Journal of American Statistical Association, 74 (366), pp. 427.

[17] Durbarry R., Gemmell N. and Greenaway D. (1998): New Evidence on the Impact of Foreign Aid on Economic Growth, CREDIT Research Paper 98/8, University of Nottingham.

[18] Easterly, W. (2003): Can foreign aid buy growth? Journal of Economic Perspectives Vol. 17. 
[19] Edwards J. R. (1994): Regression analysis as an alternative to difference scores. Journal of Management, 20, 683-689.

[20] Edwards, S. and G. Tabellini (1990): Explaining Fiscal Policies and Inflation in Developing Countries, NBER Working Paper No. 2493.

[21] Engle Robert F. and C. W. J. Granger (1987): Co-Integration and Error Correction, Representation, Estimation, and Testing, Econometrica, 55 (2): 251-276.

[22] Ekanayake E. M. and Dasha Chatrna (2011): The effect of foreign aid on economic growth in developing countries, Journal of International Business and Cultural Studies Bethune-Cookman University.

[23] Elbadawi, I. A. (1999), 'External Aid: Help or Hindrance to Export Orientation in Africa?' Journal of African Economies, 8 (4): 575-616.

[24] Fafchamps Marcel (2000): 'Engines of Growth and Africa's Economic Performance', mimeo, Centre for the Study of African Economies, University of Oxford.

[25] Feeny Simon (2005): The Impact of Foreign Aid on Economic Growth in Papua New Guinea, Journal of Development Studies, Vol. 41, No. 6, August 2005, pp. 1092-1117 ISSN 0022-0388.

[26] Feyzioglu, T., V. Swaroop and M. Zhu (1998): A panel data analysis of the fungibility of Foreign aid, World Bank Economic Review vol. 12.

[27] Fosu, A. K. (2001): Political Instability and Economic Growth in Developing Economies: Some Specification Empirics, Economics Letters 70, 289-294.

[28] Frankel, J. A. and Romer, D. (1999), 'Does Trade Cause Growth? American Economic Review, 89 (3): 379-399.

[29] Gitaru, Kelvin, 2015: Impact of Foreign Aid on Economic Growth, MPRA Paper 68145, University Library of Munich, Germany, revised 30 Jun 2016.

[30] Ghani Ejaz And Din Musleh -Ud (2006): The Impact of Public Investment on Economic Growth in Pakistan, Pakistan Development Review 45: 1 pp. 87-98.

[31] Gonamee K., Girma S. and Morrissey O. (2005): Aid and Growth in Sub-Saharan Africa. Accounting for Transmission Mechanisms, CREDIT Research Paper No. 02/05, University of Nottingham.

[32] Gounder, R., (2001): Aid-Growth Nexus: Empirical Evidence from Fiji, Applied Economics, Vol. 33, pp. 1009-19.

[33] Granger C. W. J. (1987): Developments in the Study of Cointegrated Economic Variables, Oxford Bulletin of Economics and Statistics, 48, (3), 213-28.

[34] Griffin, K. and J. Enos (1970): Foreign Assistance: Objectives and Consequences. Economic Development and Cultural Change, 18. Cambridge MA, MIT.

[35] Gupta, K. L. (1975): Foreign Capital Inflows, Dependency Burden and Savings Rates in Developing Countries; A Simultaneous Equation Model. Kyklos, Vol. 28.

[36] Gupta, K. L. and M. A. Islam (1983): Foreign Capital, Savings and Growth: An International Cross-Section Study, Boston, D. Riedel Publishing Company.

[37] Hadjimichael, M. T., D. Ghura, M. Mühleisen, R. Nord, and E.
M. Uçer (1995): Sub-Saharan Africa; Growth, savings, and Investment (1986-93), Occasional Paper 118.

[38] Harrison Ann (1996), 'Openness and Growth: A Time-Series, Cross-Country Analysis for Developing Countries', Journal of Development Economics, 48: 419-447.

[39] Hudson, John, and Paul Mosley, (2004): Aid Volatility, Policy and Development, Wider Conference.

[40] Husain, I. (1992): External Debt and Foreign Aid to Pakistan. In Anjum Naseem (eds.) Financing Pakistan's Development in the 1990s. Oxford University Press.

[41] Johansen, S. and Juselius, K. (1990), Testing Structural Hypothesis in a Multivariate Cointegration Analysis of the PPP for UK, Journal of Econometrics, 53: 211-244.

[42] Jones, C. I. (1998): Introduction to Economic Growth, New York: W. W. Norton \& Company.

[43] Karras, G. (2006), Foreign aid and long-run economic growth: empirical evidence, a panel of developing countries, Journal of International Development, vol. 18, no. 7, p. 15-28.

[44] Lavy V. and Sheffer (1991): Foreign Aid and Economic Development in the Middle East, Egypt, Syria and Jordan, New York and London, Praeger.

[45] Lensink R. and White H. (1999): Is there an Aid Laffer Curve? CREDIT Research Paper 99/6, University of Nottingham.

[46] Levine Ross and Renelt David (1992): A Sensitivity Analysis of Cross-Country Growth Regressions', American Economic Review, Vol. 82, Issue 4, 942-963.

[47] Levy, V. (1987): Aid and Growth in Sub-Saharan Africa, the Recent Experience. European Economic Review, Vol. 32.

[48] Lloyd, T., Morrissey, O. and R. Osei, (2001): 'Aid, Exports and Growth in Ghana', CREDIT Research Paper 01/01, University of Nottingham.

[49] Mahembe Edmore, Nicholas Mbaya Odhiambo and Christian Nsiah (2019): Foreign aid, poverty and economic growth in developing countries: A dynamic panel data causality analysis, Cogent Economics \& Finance, 7: 1, DOI: 10.1080/23322039.2019.1626321.

[50] M'Amanja, D., Lloyd, T. and Morrissey, O. (2005): Fiscal Aggregates, Aid and Growth in Kenya: A Vector Autoregressive (VAR) Analysis, School of Economics, University of Nottingham: CREDIT Research Paper 05/07.

[51] Mauro, P. (1995): Corruption and Growth, Quarterly Journal of Economics, Vol. 110, pp. 681-712.

[52] Mavrotas, G., and B. Ouattara (2006). Aid Disaggregation and the Public Sector in Aid Recipient Economies. Review of Development Economics.

[53] McGillivray, M., Feeny, S., Hermes, N. and R. Lensink (2006): Controversies over the impact of development aid: Journal of International Development, vol. 18, no. 7.

[54] Meier M. and Stiglitz J. (2001): Frontiers of Development Economics: The Future in Perspective, WB and Oxford University Press.

[55] Mosley, P. (1980): Aid, Savings and Growth Revisited, Bulletin of the Oxford University Institute of Economics and Statistics, Vol. 42. 
[56] Mosley, P. (1987): Overseas Aid, Its Defence and Reform, Wheat sheaf, Brighton.

[57] Papanek, G. (1973): Aid, Private Foreign Investment, Savings and Growth in Less Developed Countries, Journal of Political Economy, Vol. 81.

[58] Pesaran, H. and Shin, Y. (1996): Autoregressive Distributed Lag Modelling Approach to Co-integration Analysis, $D A E$ Working Paper No. 9514, Department of Applied Economics, University of Cambridge.

[59] Pesaran, H. R. Smith and Shin, Y. (2001): Testing for existence of Long Run relationship, DAE working paper no. 9622, Department of Applied Economics University of Cambridge.

[60] Quartey, P. (2005): Innovative ways of making aid effective in Ghana: tied aid versus direct budgetary support, Journal of International Development, vol. 17, p. 1077-1092.

[61] Ram, R. (2004), "Recipient country's 'policies' and the effect of foreign aid on economic growth in developing countries: additional evidence, Journal of International Development, vol. 16, no. 2, p. 201-211.

[62] Sala-i Martin Xavier. (1997): I Just Run Four Million Regressions, American Economic Review, May 1997, v. 87, iss. 2, pp. $178-83$.
[63] Siddique, H, M. A., Kiani, A. K. and Batool, S. (2017): The Impact of Foreign Aid on Economic Growth: Evidence from a Panel of Selected Countries. International Journal of Economics and Empirical Research. 5 (1).

[64] Tendongho Charles (2016): The Impact of Foreign Aid on the Economic Growth of Cameroon (1960-2013) Using a Multivariate Autoregressive Model. Available at SSRN: https://ssrn.com/abstract $=2948664$.

[65] Tasew Tadesse (2010): Foreign Aid and Economic Growth in Ethiopia, MPRA is a RePEc service hosted by the Munich University Library in Germany.

[66] Voivodas C. (1973): Exports, Foreign Capital Inflow and Economic growth, Journal of International Economics, Vol. 3.

[67] Weisskopf T. (1972): Impact of Foreign Capital Inflow on Domestic Savings in.

[68] Underdeveloped countries, Journal of International Economics, 2: 25-38.

[69] Xayavong V. (2002): Macroeconomic Analysis of Aid in Economic Development, A case of the Lao People's Democratic Republic, Palmerstone North, New Zealand.

[70] Yohannes B (2011): The Impact of Foreign Aid on Economic Growth in Ethiopia: Accounting for Transmission Mechanisms. Ethiopia. 